\title{
First Report of the Genus Retortamonas (Sarcomastigophora: Retortamonadidae) in Birds
}

\author{
Rafael A Martínez-Díaz/ ${ }^{+}$, Ana Teresa Castro, Silvia Herrera, Francisco Ponce*
}

Departamento de Medicina Preventiva (Parasitología), Facultad de Medicina, Universidad Autónoma de Madrid, C/ Arzobispo Morcillo s/n, 28029 Madrid, España *Departamento de Parasitología, Facultad de Farmacia, Universidad Complutense de Madrid, Madrid, España

In studies carried out on the parasites infecting ostriches (Struthio camelus) in Spain, trophozoites of Retortamonas sp. have been found in the intestinal contents of 28 out of 146 slaughtered ostriches. The species infecting ostriches could not be determined from the morphological data available. However, these findings are important as they constitute the first report of the genus Retortamonas in birds.

Key words: Retortamonas - birds - Struthio camelus

The order Retortamonadida includes flagellated protozoa living in the intestines of several invertebrate and vertebrate species. This order has only one family, the Retortamonadidae, with two genera, Retortamonas and Chilomastix. Only Chilomastix has been reported to date from birds: $C$. gallinarum Martin and Robertson, 1911, from poultry (Nie 1948).

Ostrich (Struthio camelus L) farming has become an extended activity in places where these birds did not exist previously. However, little is known about the diseases that may affect this animal. With regard to its parasites, most of the actual knowledge is about macroscopic organisms (helminths and arthropods), and few and usually incomplete data are available about its protozoa. The results we have obtained from a study started in 1997 and currently running have revealed the existence of several protozoa, including amebas (MartínezDíaz et al. 2000b), flagellates, ciliates and coccidia (Martínez Díaz et al. 2000a). Among the flagellates, we have found trophozoites of Retortamonas sp.

The biological material analyzed was the intestinal contents of 146 young ostriches (12-15 months old) slaughtered at Spanish abbatoirs between September 1997 and February 2000. The birds were born and raised in farms located in different provinces from the central area of Spain (Toledo, Ciudad Real, Cuenca, Guadalajara and Madrid). At sacrifice, all

\footnotetext{
${ }^{+}$Corresponding author. Fax: +341-397.5353. E-mail: rafael.martinez@uam.es

Received 16 April 2001

Accepted 6 June 2001
}

animals appeared healthy and with no signs of intestinal disease. Several segments of the small and large intestine and one of the caeca were excised, and their contents kept in clean, hermetic containers. All samples were transported to the laboratory in less than $2 \mathrm{~h}$ after sacrifice. Fresh slides were analized by microscopy at 100-400x; from the samples in which live trophozoites were found, several smears were made and stained with Giemsa, chlorazole black and trichromic staining.

Among other protozoa, trophozoites of Retortamonas sp. were identified in the intestinal contents of 28 birds. In fresh slides, they can be distinguished on the basis of their small size, plastic body, and slow locomotion by weak movements of its two flagella. The trophozoite (Figure) is small (Table I), usually piriform, fusiform or rounded in shape, with a large cytostome and a small nucleus near the anterior end. There is one free, anteriorlydirected flagellum and a posteriorly-directed, trailing flagellum that emerges from the cytostomal groove. The cytoplasm is not very granular but a number of vacuoles and bacteria may be present.

\section{TABLE I}

Morphometric data of Retortamonas from ostrich. All values in $\mu \mathrm{m}$

\begin{tabular}{lcc}
\hline Parameter & Mean \pm s.d. & Range \\
\hline Body length & $10.3 \pm 2.2$ & $6-14$ \\
Body width & $7.7 \pm 2.2$ & $5-13$ \\
Diameter of nucleus & $1.8 \pm 0.9$ & $1-4$ \\
Length of anterior flagellum & $7.0 \pm 1.6$ & $5-11$ \\
Length of cytostomal flagellum & $5.4 \pm 1.2$ & $4-9$ \\
\hline
\end{tabular}

$\mathrm{N}$ : 15 trophozoites measured 

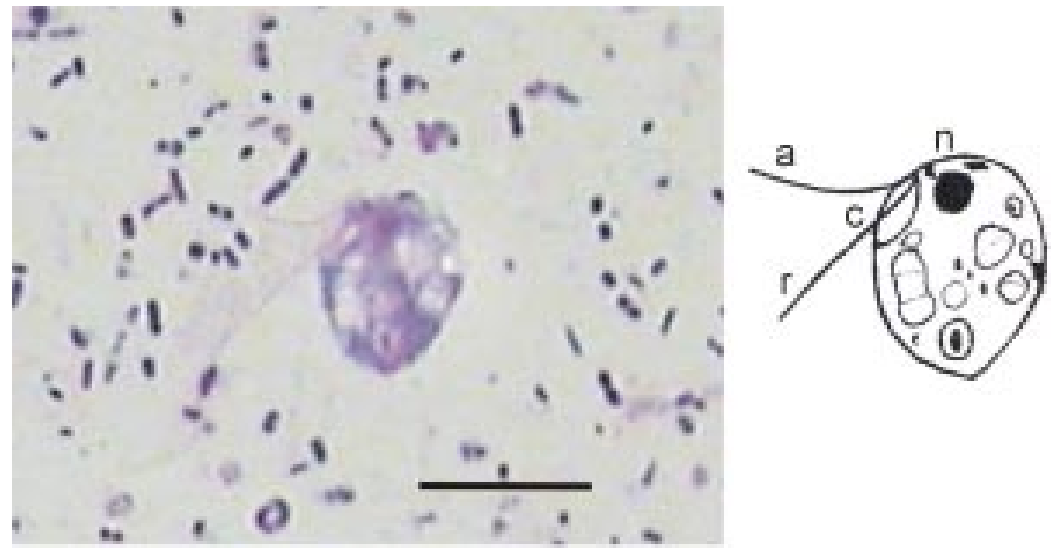

Photograph and schematic drawing of Retortamonas sp. from the ostrich. Giemsa staining; r: recurrent flagellum; a: anterior flagellum; c: cytostome; n: nucleus. Bar: $10 \mu \mathrm{m}$

In all positive samples of Retortamonas, a number of division forms showing 2 nuclei, 2 cytostomes and 4 flagella were observed. The prevalence of infection was higher during the summer months (from June to September).

The described species of Retortamonas (including those that are now considered as syn- onyms) have been found in insects, amphibians, reptiles and mammals (Table II) (Grassé 1952, Ansari 1954, Kudo 1972, Kulda \& Nohýnková 1978, Lee 1985, Levine 1985). They are very similar in their morphology, and the different species have been established mainly on the basis of the host range. The absence of cross-transmission experiments

TABLE II

Species of Retortamonas described and their hosts

\begin{tabular}{|c|c|c|}
\hline Species & Author(s) & Host(s) \\
\hline \multicolumn{3}{|l|}{ (from insects) } \\
\hline R. agilis & Mackinnon, 1919 & Tipula \\
\hline R. alexeiffi & Mackinnon, 1912 & Tipula \\
\hline R. belostomae & Brug, 1922 & Belostoma \\
\hline R. blattae & Bishop, 1931 & Cockroach \\
\hline R. caudacus & Geiman, 1932 & Aquatic coleoptera \\
\hline R. gryllotalpae & Grassi, 1879 & Mole cricket \\
\hline R. phyllophagae & Travis and Becker, 1831 & Coleoptera \\
\hline R. termitis & Kirby, 1932 & Termites \\
\hline R. wenrichi & Stabler, 1944 & Cricket \\
\hline \multicolumn{3}{|c|}{ (from amphibians and reptiles) } \\
\hline R. boae & Kulda, 1954 & Boa \\
\hline R. cheloni & Janakidevi, 1962 & Turtle \\
\hline R. dobelli & Bishop, 1931 & $\begin{array}{l}\text { Several species of } \\
\text { amphibians and reptiles }\end{array}$ \\
\hline R. testudae & Grassi, 1926 & Turtle \\
\hline \multicolumn{3}{|l|}{ (from mammals) } \\
\hline R. bradypi & Hegner and Schumaker, 1928 & Grey three-toed sloth \\
\hline R. caviae & Hegner and Schumaker, 1928 & Guinea pig \\
\hline R. cuniculi & Collier and Boeck, 1926 & Rabbit \\
\hline R. intestinalis & Wenyon and O'Connor, 1917 & Man \\
\hline R. kirbii & Russel Gabel, 1954 & Woodchuck \\
\hline R. mitrulae & Kirby and Honigberg, 1950 & Wallaroo \\
\hline R. ovis & Hegner and Schumaker, 1928 & Sheep, cattle \\
\hline$R$.ruminatum & Knowtes and Das Gupta, 1931 & Bull \\
\hline R. sinensis & Faust and Wassell, 1921 & Man \\
\hline$R$. wenyoni & Fonseca, 1917 & Monkey \\
\hline
\end{tabular}


and biochemical and genetic studies lead one to consider the possible existence of synonyms. From the data presented here, it is not possible to establish if Retortamonas from ostriches is a new species or if it corresponds to one of those previously described in other hosts. Nevertheless, the importance of the finding reported now is that this is the first time the genus Retortamonas has been found in birds. Further studies are needed to determine the taxonomic status of this organism from ostriches.

\section{REFERENCES}

Ansari MAR 1954. The genus Retortamonas Grassi. Biología Lahore 1: 40-69.

Grassé PP 1952. Traité de Zoologie, Vol. 1, Masson and Cie, Paris, 1071 pp.

Kudo RR 1972. Protozoología, Compañía Editorial Continental SA, México, 905 pp.

Kulda J, Nohýnková E 1978. Flagellates of the human intestine and intestines of other species. In JP Kreier, Parasitic Protozoa, Vol. II, Academic Press, New
York, p. 1-138.

Lee JJ 1985. Retortamonadida. In JJ Lee, SH Hutner, EC Bovee (eds), An Illustrated Guide to the Protozoa, Society of Protozoologists, Kansas, p. 118-119.

Levine ND 1985. Flagellates: Spironucleus, Giardia and other flagellates. In ND Levine, Veterinary Parasitology, Iowa State University Press, Ames, p. 89108.

Martínez Díaz RA, Castro Castellón AT, Corraleche L, López Medina N, Álvarez Ruiz N, Ponce Gordo F 2000a. Primeros datos sobre las parasitosis por protozoos en ratites en la Península Ibérica. In Globalización Medioambiental. Perspectivas Agrosanitarias y Urbanas, Ministerio de Agricultura, Pesca y Alimentación, Madrid, p. 399-404.

Martínez-Díaz RA, Herrera S, Castro AT, Ponce F 2000b. Entamoeba sp. (Sarcomastigophora: Endamoebidae) from ostriches (Struthio camelus) (Aves: Struthionidae). Vet Parasitol 92: 173-179.

Nie D 1948. The structure and division of Chilomastix intestinalis Kuczynski, with notes on similar forms in man and other vertebrates. J Morphol 82: 287 318. 
964 Report of Retortamonas in Birds - Rafael A Martínez-Díaz et al. 